\title{
PERSONAL AND EDUCATIONAL VALUES OF PUPILS FROM DIFFERENT CULTURAL BACKGROUNDS: COMPATIBILITY OR CONFLICT?
}

\author{
Iva Staňková, \& Lenka Venterová \\ Department of Pedagogical Sciences, Faculty of Humanities, Tomas Bata University in Zlín, Štefánikova \\ 5670, 76001 Zlín (Czech Republic)
}

\begin{abstract}
One of the most important and traditional values imparted by schools is that of education. However, schools are not the only institutions which channel this value. Preference for the value of education amongst elementary and secondary school pupils is strongly influenced by cultural background, represented in particular by the family or community in which the pupil is growing up. Thus the question arises of whether culture influences the preference for this value, and if so in what way. It is our conviction that the answer to this question is important for the teaching and education of individuals within schools.

As such, in our research survey we are focusing from a qualitative perspective on the significance of the value of education in the values preferences of pupils from different cultural backgrounds and on the description of partial determinants affecting the individual conception of this value, in order to acquire a comprehensive picture of how specific groups perceive education as a value. We are concentrating on two entirely different minority groups living in the Czech Republic, specifically pupils from Roma families, and pupils from intercultural families. We utilised projective method, which gave our research sample sufficient space to describe their concept of life values. For a more complete approach, we also included in-depth interviews with representatives of both groups of pupils in our investigation. In light of the research findings, we then compare personal value preferences with the values which have a basis in curricular and strategic documents regarding teaching and education at a state-wide level.
\end{abstract}

Keywords: Pupil, different cultural backgrounds, education, value, Roma, Intercultural.

\section{Introduction}

Cultural diversity is a fundamental characteristic of humankind. It is the common heritage of all human civilisations, races, ethnicities and groups, and it should be nurtured and preserved for the benefit not just of all group members, but also to help enrich other groups living in coexistence with them. In the current mobile and globalised world, various cultures which used to be more or less strictly separate frequently encounter each other, and because they do not understand each other well, severe social tension and conflicts arise. From the perspective of the cultural relativism concept (as the opposite of judging cultural differences from an ethnocentric perspective), it is presumed that individual cultures are unique and irreproducible entities and as such each culture should only be judged within its own context, in relation to its own values, ideas, norms and traditions. This is because it is clear that many cultural elements which conform to the values and manners of the cultures they are a part of do not conform to the norms and customs of other cultures. How do schools deal with this modern phenomenon of cultural diversity?

Diversity, or heterogeneity, of pupils is surely a reality in all elementary and secondary schools, which today ever more face the demand that all pupils be educated together. In practice, meeting this demand, however, stokes a whole range of issues. How specifically can one work with pupil cultural and social diversity? How can one maintain the fundamental principles of tolerance and respect for difference? How should one handle prejudices, stereotypes and labelling, and not just within education? Differences between pupils in terms of age, gender and personality are multiplied as a result of social stratification, migratory movements within society, and also as a result of the variability of conditions in which children live and grow up. From this perspective, the different cultural background of many pupils is one of the facts which the school environment must handle, or accept. Teaching and educational objectives are formed in accordance with the values society considers important. Nevertheless, these values may suppress values acknowledged within specific cultures. 
School is an institution which plays a large part in educating individuals. It seeks to ensure not just that pupils within its environment acquire merely theoretical and practical knowledge, but also that it helps shape pupils' characters in terms of attitudes and values. For education today, it would appear that the issue of values is a hot topic in terms of educational and teaching priorities. It is very important to understand values and interpret them correctly. According to Göbelová (2008), "all educational areas, all educational activities are always played within the dimensions of a certain worldview and related values focus." There are further more and more experts who are of the opinion that it is essential to help shape children's values structure within the educational process, and that this process must begin early, effectively and systematically. This worthy task would undoubtedly rise to values education, however within the Czech schools environment this important area is not a separate taught subject, in contrast to many countries in the world (e.g. values education, moral development, moral education or character education). Nevertheless, even curriculum documents at a national level accentuate the role of values within the school environment.

The requirement for values education is secured in the curricular document for elementary education in the Czech Republic, specifically the Framework Educational Programme for Elementary Education (Rámcový vzdělávací program pro základní vzdělávání, RVP ZV), which naturally monitors the appropriate ethical, moral and values objectives and tasks of teaching and education. Amongst the objectives of elementary education here we find more detailed characteristics for key competencies, which according to the RVP ZV represent a "set of knowledge, skills, abilities, attitudes and values which are important for the personal development of an individual and for the individual's participation in society." (RVP ZV, 2017, p. 10). Values education is most clearly seen within the so-called cross-curricular subjects, where we see it not as a by-product of teaching the contents of individual subjects, but as its own topic (even though "values education" is not expressly stated here).

Table 1. Cross-curricular subjects and their objectives in terms of forming pupils' attitudes and values.

\begin{tabular}{|c|c|}
\hline Cross-curricular subject: & Attitudes and values within the cross-curricular subject: \\
\hline $\begin{array}{l}\text { Moral, Character and Social } \\
\text { Education }\end{array}$ & $\begin{array}{l}\checkmark \text { helps the pupil create a positive (non-harmful) attitude towards oneself } \\
\text { and others } \\
\checkmark \\
\text { guides the pupil towards realising the value of co-operation and } \\
\text { assistance } \\
\checkmark \quad \text { guides the pupil towards realising the value of human diversity, } \\
\text { differences in opinions and approaches to solving problems } \\
\checkmark \quad \text { contributes to realising the moral dimensions of various types of } \\
\text { human behaviour } \\
\checkmark \text { contributes to the primary prevention of sociopathic phenomena and } \\
\text { harmful forms of behaviour }\end{array}$ \\
\hline Civic Education for Democracy & $\begin{array}{l}\checkmark \text { guides the pupil towards adopting an open, active and involved } \\
\text { approach to life } \\
\checkmark \text { teaches respect for the law } \\
\checkmark \text { develops discipline and self-criticism } \\
\checkmark \text { teaches self-esteem and self-confidence, independence and } \\
\text { engagement } \\
\checkmark \text { contributes to the formation of values such as justice, freedom, } \\
\text { solidarity, tolerance and responsibility } \\
\checkmark \text { develops and supports the pupil's ability to take his/her own stance in a } \\
\text { plurality of opinions } \\
\checkmark \text { motivates the pupil to be considerate and willing to help others, } \\
\checkmark \text { particularly those weaker than he/she is } \\
\text { makes it possible to judge and evaluate social phenomena, processes, } \\
\text { events and issues from various perspectives (local, national, European } \\
\text { and global dimensions) } \\
\checkmark \text { guides the pupil towards respecting cultural, ethnic and other } \\
\text { differences } \\
\checkmark \text { guides the pupil towards being assertive and being able to compromise }\end{array}$ \\
\hline $\begin{array}{l}\text { Education towards Thinking in } \\
\text { European and Global Contexts }\end{array}$ & 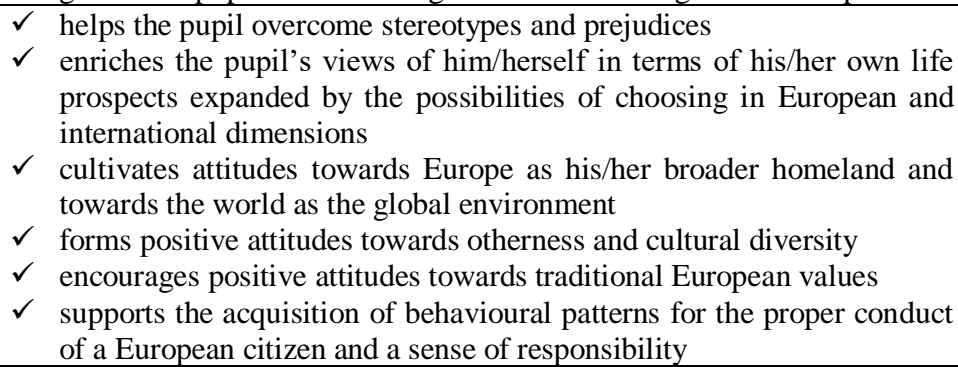 \\
\hline
\end{tabular}




\begin{tabular}{|c|c|}
\hline Multicultural Education & $\begin{array}{l}\text { helps bring the pupil by means of information to form attitudes of } \\
\text { tolerance and respect towards different socio-cultural groups, reflect on } \\
\text { the cultural background of members of other socio-cultural groups and } \\
\text { recognise them } \\
\checkmark \text { helps the pupil become aware of his/her own identity, be him/herself, } \\
\text { reflect on his/her own socio-cultural background } \\
\checkmark \quad \text { stimulates, influences and corrects the pupil's behaviour and value } \\
\text { system, and teaches him/her to perceive diversity as an opportunity for } \\
\text { personal enrichment and not as a source of conflict } \\
\checkmark \text { helps the pupil to realise the incompatibility of racial (religious or } \\
\text { other) intolerance with the principles of living in a democratic society } \\
\checkmark \text { guides the pupil towards engagement in fighting manifestations of } \\
\text { intolerance, xenophobia, discrimination and racism } \\
\checkmark \text { teaches the pupil to perceive him/herself as a citizen who participates } \\
\text { actively in forming the society's relationship to minority groups }\end{array}$ \\
\hline Environmental Education & $\begin{array}{l}\checkmark \text { contributes to the pupil perceiving life as the highest value } \\
\checkmark \text { guides the pupil towards becoming responsible in his/her relationship } \\
\text { to the biosphere, nature preservation and conservation of natural } \\
\text { resources } \\
\checkmark \text { guides the pupil towards understanding the importance and necessity } \\
\text { of sustainable development as a positive prospect for the further } \\
\text { development of human society } \\
\checkmark \quad \text { stimulates activity, creativity, tolerance, being accommodating and } \\
\text { considerate in his/her relationship to the environment } \\
\checkmark \quad \text { contributes to the pupil shaping a healthy lifestyle and becoming aware } \\
\text { of the aesthetic values of the environment } \\
\checkmark \text { guides the pupil towards becoming engaged in solving issues } \\
\text { associated with environmental protection } \\
\checkmark \text { guides the pupil towards adopting a perceptive and sensitive approach } \\
\text { to nature and natural and cultural heritage }\end{array}$ \\
\hline Media Education & $\begin{array}{l}\checkmark \text { develops the pupil's sensitivity to stereotypes found in media content } \\
\text { as well as to the manner in which a media message has been treated } \\
\checkmark \\
\text { guides the pupil towards realising the value of his/her life (in particular } \\
\text { leisure time) and his/her responsibility for its fulfilment } \\
\checkmark \quad \text { develops sensitivity to prejudices and simplified judgements of society } \\
\text { (in particular of minorities) as well as individuals } \\
\checkmark \quad \text { helps the pupil realise the possibility of freely expressing his/her } \\
\text { personal attitudes and responsibility for how they are formulated and } \\
\text { presented }\end{array}$ \\
\hline
\end{tabular}

From the above table, it is clear that elementary education at Level 2 (ISCED 2) in the Czech Republic helps pupils to acquire the knowledge, skills and habits which will subsequently enable them to learn independently and form such values and attitudes which will lead to judicious and cultivated conduct, to responsible decision-making and to respecting the rights and responsibilities of a citizen of our country and the European Union (RVP ZV, 2017, p. 8)

\section{Objectives/methods}

The objective of our research was to identify what personal values pupils within selected research samples prefer, and whether these values are in accordance with the educational values within the Czech education system.

In the research, pupils were selected who met the criteria determined for the following two research samples:

$1^{\text {st }}$ research sample

- Pupils within an intercultural family environment. *

- Pupils in lower secondary education (ISCED 2).

$2^{\text {nd }}$ research sample

- Pupils in lower secondary education (ISCED 2).

- Roma pupils

* Due to inconsistencies in the definition of an intercultural family environment, we included in the criteria for selecting families those families in which partners came from different cultures and spoke different native tongues. 


\section{Research model}

Since we wanted our pupils to think about their values, we didn't want to merely fill in submitted tables with values, and the following written task was given to them using a projective method:

What do you consider important in your life and why?

They were given sufficient time and space to order and write out their own thoughts, leading them to expand not just on their naming of values, but also on their interpretations of why the particular values are important to them.

\section{Results}

Below, we provide a comparison of the most significant values which the lower secondary-level education pupils stated in their responses. The values are ordered in accordance with frequency.

\section{PROJECTIVE METHOD DATA}

Table 2. Values the pupils consider the most important in life.

\begin{tabular}{|l|l|l|}
\hline Order & Roma pupils & Pupils from intercultural families \\
\hline 1. & Family & Family and children \\
\hline 2. & Love and relationships & Friends \\
\hline 3. & Children & Education \\
\hline 4. & Good health & Sport \\
\hline 5. & Work & Happiness \\
\hline 6. & Education, intelligence & Fun \\
\hline 7. & Self-fulfilment, interests & Hobbies \\
\hline 8. & Friends & Creativity \\
\hline 9. & Home & Having enough money \\
\hline 10. & Money & God (faith) \\
\hline
\end{tabular}

\section{DATA FROM IN-DEPTH INTERVIEWS}

Table 3. The most significant values which pupils consider to be important in life.

\begin{tabular}{|l|l|}
\hline Roma pupils & Pupils from intercultural families \\
\hline Mutual help within the community & Family, home \\
\hline Family and community belonging & Education \\
\hline Family and relationships & Privacy \\
\hline Education and self-development & Peers \\
\hline Value of life & (Future) occupation \\
\hline Quality work & Having enough money \\
\hline & Developing own personality \\
\hline & Leisure time \\
\hline & Faith \\
\hline
\end{tabular}

\section{Conclusions}

The values systems of pupils from different cultural environments are not the same, and as such these pupils must be worked with individually within values education. Roma pupils are more altruistic, which is apparent from the values they spoke of in the in-depth interviews (mutual help within the community, family and community belonging). Within their culture, these values are natural. These findings should be exploited in education and training, such as through group and co-operative learning. Values are preferred which are linked to the family and relationships in general; Roma pupils are particularly sensitive within this area, and the development of social relationships comes naturally to 
them. On the other hand, the preference for the values of education and their own self-development needs to be strengthened.

Pupils from an intercultural environment work as a counterpole, and since from a young age they have encountered the mixing of at least two cultures and different mother tongues within the family environment, they are focused more on their own personality, rewards and materialism. This is clear from the values they described (education, having enough money, (future) occupation, development of their own personality). On the other hand, faith is regularly positioned low in their rankings, and they do not mention community at all within their values rankings. This is confirmed by Breger and Hill (1998), who state that these individuals, or specifically their parents, do not have a faith and are well-educated. Staňková and Venterová (2017) came to similar conclusions. For these pupils, it is therefore appropriate to strengthen co-operation and cohesion within the group. In terms of RVP ZV cross-curricular subjects, this involves more intensive strengthening of the cross-curricular subject Moral, Character and Social Education.

\section{Acknowledgements}

This article was based on the grant project IGA SV60171706020 / 2110 - The concept of educational values from the perspective of pupils from different cultural backgrounds. However, any mistakes that remain are my own.

\section{References}

Breger, R., Hill, R. (1998). Cross-cultural marriage: Identity and choice. New York: Bergamon Göbelová, T. (2008). Hodnotová výchova v pedagogické praxi. Ostrava: Ostravská univerzita.

Rámcový vzdělávací program pro základní vzdělávání, Praha, 2017. Available at: http://www.msmt.cz/file/41216/

Staňková, I., Venterová, L. (2017). The concept of educational values from the perspective of pupils from different cultural backgrounds. In: Edukacija malego dziecka. Teoretyczna odniesienia, tendencje i problemy. Krakow: Wydzial Etnologii i Nauk o Edukacji Uniwersytetu Slaskiego. 